\title{
PHOTO-FENTON REACTION OF DYES WITH Fe(III)-TREATED HYDROXYAPATITES AS HETEROGENEOUS CATALYSTS IN WATER
}

\author{
Takeshi Moriguchi $^{1 *}$, Souhei Nakagawa ${ }^{2}$ \\ (*Corresponding author: tksmorig@ saitama-med.ac.jp) \\ ${ }^{1}$ Department of Chemistry, Saitama Medical University \\ 38 Morohongo, Moroyama-machi, Iruma-gun, Saitama 350-0495, Japan \\ ${ }^{2} \mathrm{R} \&$ D Division, Taihei Chemical Industrial Co., Ltd. \\ 1-1 Takayasu, Ikaruga-cho, Ikoma-gun, Nara 636-0104, Japan
}

Keywords: Iron-treated hydroxyapatite, Photo-Fenton reaction, Dye

\begin{abstract}
Fe(III)-treated hydroxyapatites, HAP-300-Fe and HAP-400-Fe, were prepared from hydroxyapatites, HAP-300 (stoichiometric type) and HAP-400 (Ca-deficient type), respectively, and applied to photo-Fenton reaction of dyes as heterogeneous catalysts in comparison with other $\mathrm{Fe}$ catalysts such as $\mathrm{Fe}_{2} \mathrm{O}_{3}, \mathrm{FePO}_{4} \cdot 2 \mathrm{H}_{2} \mathrm{O}$, and $\mathrm{FeOOH}$. Among the $\mathrm{Fe}$ catalysts, HAP-400-Fe revealed the highest consumption and mineralization in photo-Fenton reaction of alizarin red S (ARS), and also indicated good catalytic activity to other dyes, alizarin, neutral red, methyl red, methyl orange (MO), Congo red, and indigo carmine. Generation of hydroxyl radical $\bullet \mathrm{OH}$ as an oxidation species from $\mathrm{H}_{2} \mathrm{O}_{2}$ was observed in the all $\mathrm{Fe}$ catalysts by an indirect method using $\mathrm{N}, \mathrm{N}$-dimethylamino-4-nitrosoaniline, which is exclusively sensitive to $\bullet \mathrm{OH}$. In order to elucidate catalysis mechanism of Fe catalysts, kinetic investigation based on Michaelis-Menten theory was conducted in the reaction of ARS and MO. As a result, HAP-400-Fe indicated high ability of bearing many dye molecules but low degradative catalysis ability to $\mathrm{H}_{2} \mathrm{O}_{2}$, compared with $\mathrm{Fe}_{2} \mathrm{O}_{3}$. However, judging from high mineralization ability as well as repeating availability (5 times), HAP-400-Fe is considered as an excellent heterogeneous catalyst for photo-Fenton reaction.
\end{abstract}

(Received February 24 2011; Accepted March 12 2012)

\section{INTRODUCTION}

In the previous paper, ${ }^{1}$ we reported adsorbability of alizarin red $\mathrm{S}$ (ARS) as a born-staining agent ${ }^{2}$ onto $\mathrm{Fe}(\mathrm{III})$ - and $\mathrm{Pb}(\mathrm{II})$-treated hydroxyapatites, which are prepared from stoichiometric hydroxyapatite $\mathrm{Ca}_{10}\left(\mathrm{PO}_{4}\right)_{6}(\mathrm{OH})_{2}, \quad$ HAP-300 $(\mathrm{Ca} / \mathrm{P}=1.68$, slightly containing $\mathrm{CO}_{3}$ ), and Ca-deficient hydroxyapatite $\mathrm{Ca}_{10-\mathrm{x}}\left(\mathrm{HPO}_{4}\right)_{\mathrm{x}}\left(\mathrm{PO}_{4}\right)_{6-\mathrm{x}}(\mathrm{OH})_{2-\mathrm{x}}, \quad \mathrm{HAP}-400 \quad(\mathrm{Ca} / \mathrm{P}=1.38)$. Among those metal-treated apatites, Fe(III)-treated hydroxyapatites, HAP-300-Fe and HAP-400-Fe, indicated higher adsorption capacities than the raw apatites, HAP-300 and HAP-400. From IR analysis, an adsorption mechanism between $\mathrm{Fe}$ (III)-treated hydroxyapatites and ARS was defined as chelete form constructed by chelation of two functional groups of $\mathrm{ARS}, 1-\mathrm{C}-\mathrm{O}^{-}$and $9-\mathrm{C}=\mathrm{O}$, to a $\mathrm{Fe}$ site of each $\mathrm{Fe}$ (III)-treated apatite. The chelate form adsorption is rigid and hardly subjected to desorption even by treatment with an aqueous solution containing phosphate ions.

Judging from those adsorbabilities, we expected that the $\mathrm{Fe}(\mathrm{III})$-treated hydroxyapatites are to be useful as heterogeneous catalysts for photo-Fenton reaction. $^{3-18}$ Photo-Fenton reaction is one of advanced oxidation processes, ${ }^{19}$ which are essentially used for removal of natural organic matter from drinking water. Although some homogeneous photo-Fenton systems using $\mathrm{Fe}$ ions ${ }^{20-25}$ feature a merit of powerful degradation of organic compounds, they have a disadvantage of requirement to remove Fe ions from water after water treatment. ${ }^{9}$ From a viewpoint of smoothing and recycling usage, or running cost in future water purification plants, a heterogeneous system must be superior to homogenous one. As heterogeneous catalysts, iron oxides $\left(\mathrm{Fe}_{2} \mathrm{O}_{3}, \quad \mathrm{FeOOH}\right),{ }^{3,13} \mathrm{Fe}(\mathrm{III})$-immobilized zeolites, ${ }^{4,11,12}$ Fe(III)-immobilized silica, ${ }^{5,16}$ Fe(III)-immobilized clay, ${ }^{6-9,14,17} \mathrm{Fe}(\mathrm{III})$-immobilized $\mathrm{Al}_{2} \mathrm{O}_{3},{ }^{10}$ Prussian blue colloids, ${ }^{15}$ and tungstate salt $^{18}$ were employed so far. However, Fe-hybridized hydroxyapatites such as HAP-300-Fe and HAP-400-Fe for heterogeneous photo-Fenton catalysts have never been reported. Since a raw hydroxyapatite as a catalyst base is originally biocompatible $^{26}$ and has adsorption capacity in water, ${ }^{27}$ no problem will be raised in water treatment. Therefore, we investigated photo-Fenton reaction of organic dyes with HAP-300-Fe or HAP-400-Fe in water and elucidated its catalysis mechanism by a kinetic study based on Michaelis-Menten theory. 
<smiles>O=C1c2ccccc2C(=O)c2c1cc(S(=O)(=O)O)c(O)c2O</smiles>

Alizarin Red S (ARS)<smiles>O=C1c2ccccc2C(=O)c2c1ccc(O)c2O</smiles>

Alizarin<smiles>Cc1cc2nc3ccc(=[N+](C)C)cc-3[nH]c2cc1C</smiles>

Neutral Red<smiles>CN(C)c1ccc(N=Nc2ccccc2C(=O)O[Na])cc1</smiles>

Methyl Red

Congo Red<smiles>CN(C)c1ccc(N=Nc2ccc(S(=O)(=O)O[Na])cc2)cc1</smiles>

Methyl Orange (MO)<smiles>CS(=O)(=O)c1ccc2c(c1)C(=O)/C(=C1/Nc3ccc(S([O])(=O)=O)cc3C1=O)N2</smiles>

Indigo Carmine

SCHEME 1 Structures of dyes as substrates in photo-Fenton reaction.

\section{MATERIALS AND METHODS}

\subsection{Materials}

Hydroxyapatites, HAP-300 and HAP-400, which were synthesized from $\mathrm{CaHPO}_{4} \cdot 2 \mathrm{H}_{2} \mathrm{O}$ and $\mathrm{CaCO}_{3}$ and from $\mathrm{CaHPO}_{4} \cdot 2 \mathrm{H}_{2} \mathrm{O}$ and $\mathrm{NaOH},{ }^{28,29}$ respectively, were supplied from Taihei Chemical Industrial Co., Ltd. Alizarin red S (ARS), alizarin, neutral red, methyl red, methyl orange (MO), Congo red, and indigo carmine as dyes (SCHEME 1), iron (III) chloride hexahydrate $\mathrm{FeCl}_{3} \cdot 6 \mathrm{H}_{2} \mathrm{O}$ (purity $99.9 \%$ ), distilled water $\left(\mathrm{H}_{2} \mathrm{O}\right)$, phosphate buffer solution (PBS) at pH 6.86 containing $25 \mathrm{mM} \mathrm{KH}_{2} \mathrm{PO}_{4}, 25 \mathrm{mM}$ $\mathrm{Na}_{2} \mathrm{HPO}_{4}$, and about $0.1 \% \mathrm{NaN}_{3}, 30 \% \mathrm{H}_{2} \mathrm{O}_{2}$ aqueous solution, and N, N-dimethyl-4-nitrosoaniline (DMNA, SCHEME 2) were purchased from Wako Pure Chemical Industries, Ltd., Osaka, Japan. All chemicals were used without further purification.

\subsection{Preparation of Fe(III)-treated hydroxyapatites}

According to the previous papers, $1, \quad 30$ Fe(III)-treated hydroxyapatites were synthesized as follows. To $0.50 \mathrm{~g}$ of hydroxyapatite (HAP-300 or HAP-400) with a stirrer tip in a $200 \mathrm{~mL}$ eggplant-shaped flask was added $100 \mathrm{~mL}$ of $25 \mathrm{mM}$ aqueous solution of $\mathrm{FeCl}_{3}$. The mixture was shaken at $25^{\circ} \mathrm{C}$ for $4 \mathrm{~h}$ in a concussive water incubator, M-100N, (TAITEC Co., Ltd. Saitama, Japan), and centrifuged at $3000 \mathrm{rpm}$ with a centrifuge, Model B (Shimadzu Co., Kyoto, Japan) to recover product material. This material was washed three times with $\mathrm{H}_{2} \mathrm{O}$ and dried at $150^{\circ} \mathrm{C}$ overnight in a drying oven, DZ-54 (Yamato Scientific Co., Ltd., Tokyo, Japan) to obtain Fe(III)-treated hydroxyapatites, HAP-300-Fe $(\mathrm{Ca} 6.27 \%, \mathrm{P} 15.8 \%, \mathrm{Fe} 28.15 \%,(\mathrm{Ca}+\mathrm{Fe}) / \mathrm{P}=1.29)$ and HAP-400-Fe (Ca 4.39\%, P 17.76\%, Fe 28.51\%, $(\mathrm{Ca}+\mathrm{Fe}) / \mathrm{P}=1.08)$. These Fe-treated apatites contained $5.0 \mathrm{mmol} / \mathrm{g}$ of Fe. Chlorine element was not detected in the Fe(III)-treated apatites. As shown in FIGURE 1 and 2, IR spectra and X-ray diffraction patterns of the Fe-treated apatites were in good accordance with the previous reports. ${ }^{1,30}$ Specific surface areas and total pore volumes of the Fe-treated apatites were analyzed by BET method with a high speed gas sorption analyzer Nova 1000, type N10-12 (Yuasa Ionics Co., Ltd., Japan, or Malvern Instruments Ltd., UK), and were summarized in TABLE 3. As an alternate, low Fe(III)-loaded 
hydroxyapatites containing $1.0 \mathrm{mmol} \mathrm{Fe} / \mathrm{g}$ and 2.5 $\mathrm{mmol} \mathrm{Fe} / \mathrm{g}$ were prepared by the similar method, in which $5.0 \mathrm{mM}$ and $12.5 \mathrm{mM} \mathrm{FeCl}_{3}$ aqueous solutions were used, respectively. XRD patterns of those $\mathrm{Fe}$ apatites were shown in FIGURE 2, where it was confirmed that $\mathrm{Fe}(\mathrm{III})$-treated hydroxyapatites containing $5.0 \mathrm{mmol} \mathrm{Fe} / \mathrm{g}$, HAP-400-Fe, eventually had amorphic $\mathrm{FePO}_{4}$ phases (FIGURE 2c). ${ }^{30}$

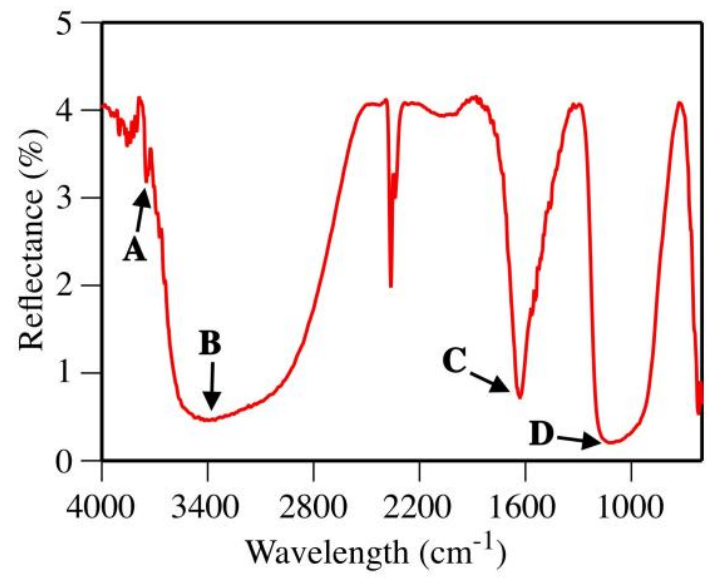

FIGURE 1 IR spectrum of HAP-400-Fe. ${ }^{1,30}$ A, surface $\mathrm{OH}$ stretching; $\mathrm{B}$, internal $\mathrm{OH}$ stretching; $\mathrm{C}$, adsorbed $\mathrm{H}_{2} \mathrm{O}$ bending; $\mathrm{D}, \mathrm{PO}_{4}$ stretching.

\subsection{Photo-Fenton reaction}

A typical reaction method was as follows. To $10 \mathrm{mg}$ of $\mathrm{Fe}$ (III)-treated hydroxyapatite, HAP-300-Fe or HAP-400-Fe $(2.5 \mathrm{mmol} \mathrm{Fe} / \mathrm{L})$, in a transparent glass bottle was added $10 \mathrm{~mL}$ of $20 \mathrm{mM} \mathrm{H} \mathrm{H}_{2} \mathrm{O}_{2}$ aqueous solution, followed by immediate addition of $10 \mathrm{~mL}$ of $46 \mu \mathrm{M}$ dye (ARS, MO, alizarin, neutral red, methyl red, Congo red, or indigo carmine) aqueous solution, of which $\mathrm{pH}$ had been adjusted to 7.0. The actual reaction concentrations were $23 \mu \mathrm{M}$ for dye and $10 \mathrm{mM}$ for $\mathrm{H}_{2} \mathrm{O}_{2}$. After the mixture bottle was tightly closed with a screw cap, it was placed and shaken at $25^{\circ} \mathrm{C}$ for $6 \mathrm{~h}$ in the concussive water incubator under black light irradiation $\left(370 \mathrm{~mW} / \mathrm{cm}^{2}\right.$ at $365 \mathrm{~nm}$ ). The resulting mixture was filtered via a PTFE membrane filter with $0.45 \mu \mathrm{m}$ pores, DISMIC-13HP (ADVANTEC Toyo Roshi Kaisha, Ltd., Tokyo, Japan), and the filtrate was analyzed with a UV-VIS spectrophotometer, U-2000, (Hitachi Ltd., Tokyo, JAPAN) equipped with a temperature controller, SDR-30, (KELK Ltd., Kanagawa, JAPAN) for elucidation of consumption of dye, and with a total organic carbon (TOC) analyzer, TOC-V $\mathrm{V}_{\mathrm{CSN}}$ (Shimadzu Co., Kyoto, Japan) for elucidation of mineralization of dye. In the UV-VIS analysis, the following wavelengths were
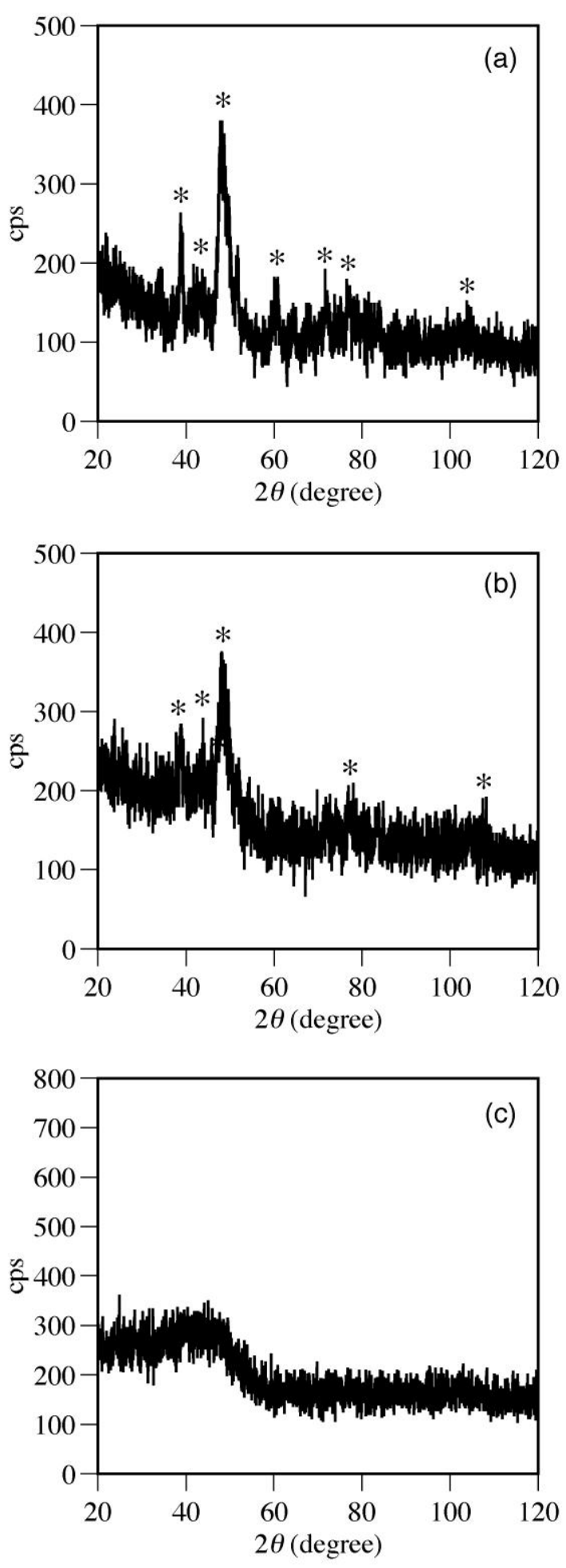

FIGURE 2 XRD patterns of $\mathrm{Fe}$ (III)-treated HAP-400 catalysts: (a) $1.0 \mathrm{mmol} \mathrm{Fe} / \mathrm{g}$; (b) $2.5 \mathrm{mmol}$ $\mathrm{Fe} / \mathrm{g}$; (c) $5.0 \mathrm{mmol} \mathrm{Fe} / \mathrm{g}$ (HAP-400-Fe). The peaks with asterisks are assigned to raw hydroxyapatite (HAP-400). X-ray source, $\mathrm{Cr}$. 
employed as $\lambda_{\max }$ values: $518 \mathrm{~nm}$ for ARS, $463 \mathrm{~nm}$ for MO, $518 \mathrm{~nm}$ for alizarin, $522 \mathrm{~nm}$ for neutral red, $435 \mathrm{~nm}$ for methyl red, $498 \mathrm{~nm}$ for Congo red, 610 $\mathrm{nm}$ for indigo carmine. As control tests, $\mathrm{Fe}_{2} \mathrm{O}_{3}$, $\mathrm{FePO}_{4} \cdot 2 \mathrm{H}_{2} \mathrm{O}$, and $\mathrm{FeOOH}$ were used as catalysts $(2.5$ $\mathrm{mmol} \mathrm{Fe} / \mathrm{L}$ ) in photo-Fenton reaction of dyes under the same condition.

\subsection{Observation of Fe elution from Fe catalysts}

After the photo-Fenton reaction of ARS using all Fe catalysts described above (Section 2.3), all the filtrates from reaction solutions were analyzed by an inductively coupled plasma atomic emission spectrometer (ICP), SPS3100 (Seiko Instruments Inc., Chiba, Japan) to observe Fe elution concentrations from the Fe catalysts.

\subsection{Kinetic method}

Kinetic investigation based on Michaelis-Menten theory ${ }^{31}$ for photo-Fenton reaction was carried out as follows. To Fe catalyst, HAP-300-Fe, HAP-400-Fe, or $\mathrm{Fe}_{2} \mathrm{O}_{3}(2.5 \mathrm{mmol} \mathrm{Fe} / \mathrm{L})$, in a transparent glass bottle was added $10 \mathrm{~mL}$ of $20 \mathrm{mM} \mathrm{H} \mathrm{H}_{2} \mathrm{O}_{2}$ aqueous solution, followed by immediate addition of $10 \mathrm{~mL}$ of 11.5 96 $\mu \mathrm{M}$ dye (ARS or MO) aqueous solution, of which $\mathrm{pH}$ had been adjusted to 7.0. The actual reaction concentrations were 5.6 46 $\mu \mathrm{M}$ for dye and $10 \mathrm{mM}$ for $\mathrm{H}_{2} \mathrm{O}_{2}$. After the mixture bottle was tightly closed with a screw cap, it was placed and shaken at $25^{\circ} \mathrm{C}$ in the concussive water incubator under black light irradiation $\left(370 \mathrm{~mW} / \mathrm{cm}^{2}\right.$ at 365 $\mathrm{nm})$. The reaction times were $15 \mathrm{~min}$ for ARS and 4 $\mathrm{h}$ for MO. The resulting solution was filtered via the PTFE membrane filter with $0.45 \mu \mathrm{m}$ pores, and the filtrate was analyzed with the UV-VIS spectrophotometer equipped with the temperature controller for elucidation of consumption of dye. From Lineweaver-Burk plotting ${ }^{32}$ (referred to FIGURE 9 and 10), the corresponding kinetic constants were evaluated (referred to TABLE 4). As a control test, an investigation using PBS as a solvent was also carried out.

Similar kinetic investigation for observation of hydroxyl radical generation under the photo-Fenton reaction condition was carried out, referred to Bors' method. $^{33}$ To an iron catalyst, HAP-400-Fe or $\mathrm{Fe}_{2} \mathrm{O}_{3}(2.5 \mathrm{mmol} \mathrm{Fe} / \mathrm{L})$, in a transparent glass bottle was added $10 \mathrm{~mL}$ of $20 \mathrm{mM} \mathrm{H} \mathrm{O}_{2}$ aqueous solution, followed by immediate addition of $10 \mathrm{~mL}$ of 5.0 80 $\mu \mathrm{M}$ DMNA aqueous solution. The actual reaction concentrations were $2.5 \sim 40 \mu \mathrm{M}$ for dye and $10 \mathrm{mM}$ for $\mathrm{H}_{2} \mathrm{O}_{2}$. After the mixture bottle was tightly closed with a screw cap, it was placed and shaken at $25^{\circ} \mathrm{C}$ for $1 \mathrm{~h}$ in the concussive water incubator under black light irradiation $\left(370 \mathrm{~mW} / \mathrm{cm}^{2}\right.$ at $\left.365 \mathrm{~nm}\right)$. Similarly to the above kinetic method using dyes, consumption of DMNA was determined by UV-VIS spectroscopy $\left(\lambda_{\max } 440 \mathrm{~nm}\right)$, and kinetic constants were determined by Lineweaver-Burk plotting (referred to FIGURE 12 and TABLE 4).

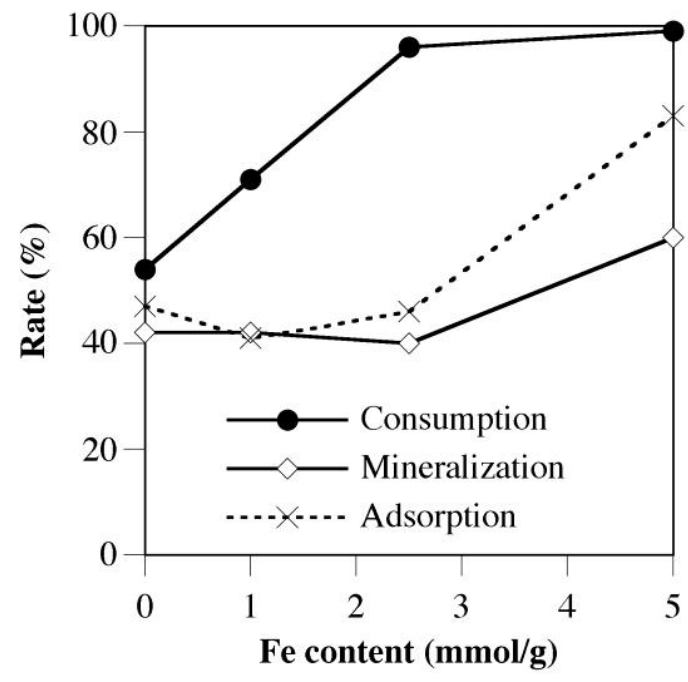

FIGURE 3 Consumption, mineralization, and adsorption of ARS $(23 \mu \mathrm{M})$ under photo-Fenton reaction condition $\left(25^{\circ} \mathrm{C}, 6 \mathrm{~h}\right)$ with $\mathrm{Fe}(\mathrm{III})$-treated HAP-400 catalysts containing 1.0, 2.5, and 5.0 (HAP-400-Fe) mmol Fe/g. The adsorption test was conducted without $\mathrm{H}_{2} \mathrm{O}_{2}$ and black light irradiation.

\section{RESULTS AND DISCUSSION}

\subsection{Effect of Fe treatment of hydroxyapatite}

In order to confirm effect of $\mathrm{Fe}(\mathrm{III})$ treatment of hydroxyapatite, photo-Fenton reaction of ARS was investigated at $25^{\circ} \mathrm{C}$ for $6 \mathrm{~h}$ with $\mathrm{Fe}$ (III)-treated HAP-400 catalysts, which have different Fe contents, 1.0, 2.5, and $5.0 \mathrm{mmol} \mathrm{Fe} / \mathrm{g}$. FIGURE 3 reveals rates of consumption and mineralization of ARS: Consumption means conversion of ARS, and mineralization means ultimate oxidation to $\mathrm{CO}_{2}$ and $\mathrm{H}_{2} \mathrm{O}$. In addition, ARS adsorption rate under the similar reaction condition without $\mathrm{H}_{2} \mathrm{O}_{2}$ and black light irradiation was shown in FIGURE 3. In the case of photo-Fenton reaction with a raw apatite, HAP-400 (0 mmol Fe/g), ARS was consumed over $50 \%$. Judging from adsorption result, the consumption rate is mostly attributed to adsorption to HAP-400 and slightly to $\mathrm{H}_{2} \mathrm{O}_{2}$ oxidation activated by 
black light irradiation. The mineralization rate by using HAP-400 is truthfully due to adsorption removal. Photo-Fenton reaction with the Fe(III)-treated HAP-400 catalysts containing 1.0 and $2.5 \mathrm{mmol} \mathrm{Fe} / \mathrm{g}$ resulted in increase in ARS consumption, which was obviously depended on $\mathrm{Fe}$ contents. However, adsorption of ARS using those Fe(III)-treated HAP-400 catalysts resulted in adsorption quantities resembling in the case of HAP-400. We confirmed that the Fe treatment apparently afforded catalytic activity to hydroxyapatite for photo-Fenton reaction. Further increase in $\mathrm{Fe}$ content up to $5.0 \mathrm{mmol} \mathrm{Fe} / \mathrm{g}$, namely HAP-400-Fe, induced almost complete consumption of ARS and $60 \%$ mineralization (referred to TABLE 1 and 2). The mineralization value (60\%) was apparently less than the adsorption rate by using HAP-400-Fe, this can be explained by the following reason. The adsorption investigation was conducted in the absence of $\mathrm{H}_{2} \mathrm{O}_{2}$, and ARS must be instantly adsorbed on the apatic catalysts. Actually, after the investigation, HAP-400-Fe was stained. On the other hand, photo-Fenton reaction investigation was conducted in the presence of $\mathrm{H}_{2} \mathrm{O}_{2}$, and competitive adsorption of both ARS and $\mathrm{H}_{2} \mathrm{O}_{2}$ molecules onto HAP-400-Fe possibly occurs. Therefore, adsorbability of ARS during photo-Fenton reaction must be depressed. Actually, after the reaction, HAP-400-Fe was hardly stained. In addition, adsorption of $\mathrm{H}_{2} \mathrm{O}_{2}$ on HAP-400-Fe in the absence of dyes was truly observed, as shown in FIGURE 4 (white circles, "HAP-400-Fe (no light)"). The concentration of $\mathrm{H}_{2} \mathrm{O}_{2}, 10 \mathrm{mM}$, at the present photo-Fenton reaction was much larger than that of ARS, $23 \mu \mathrm{M}$, and adsorbability of ARS must have been further depressed during the reaction. Therefore, the mineralization rate at $60 \%$ by using HAP-400-Fe was almost caused by ultimate oxidation to $\mathrm{CO}_{2}$ and $\mathrm{H}_{2} \mathrm{O}$.

\subsection{Difference in hydroxyapatite}

As an alternative $\mathrm{Fe}(\mathrm{III})$-treated hydroxyapatite, HAP-300-Fe $(5.0 \mathrm{mmol} \mathrm{Fe} / \mathrm{g})$ was prepared from hydroxyapatite HAP-300 as a stoichiometric apatite under the same as the preparation condition of HAP-400-Fe. In order to compare catalytic activities between HAP-300-Fe and HAP-400-Fe, photo-Fenton reaction of ARS was investigated at $25^{\circ} \mathrm{C}$ for $2 \mathrm{~h}$ by using those $\mathrm{Fe}(\mathrm{III})$-apatic catalysts. The result was shown by time-dependent consumption curves in FIGURE 5, where filled circles on a solid line are for HAP-400-Fe and filled squares on a solid line are for HAP-300-Fe. As a control test ("no light"), photo-Fenton reaction
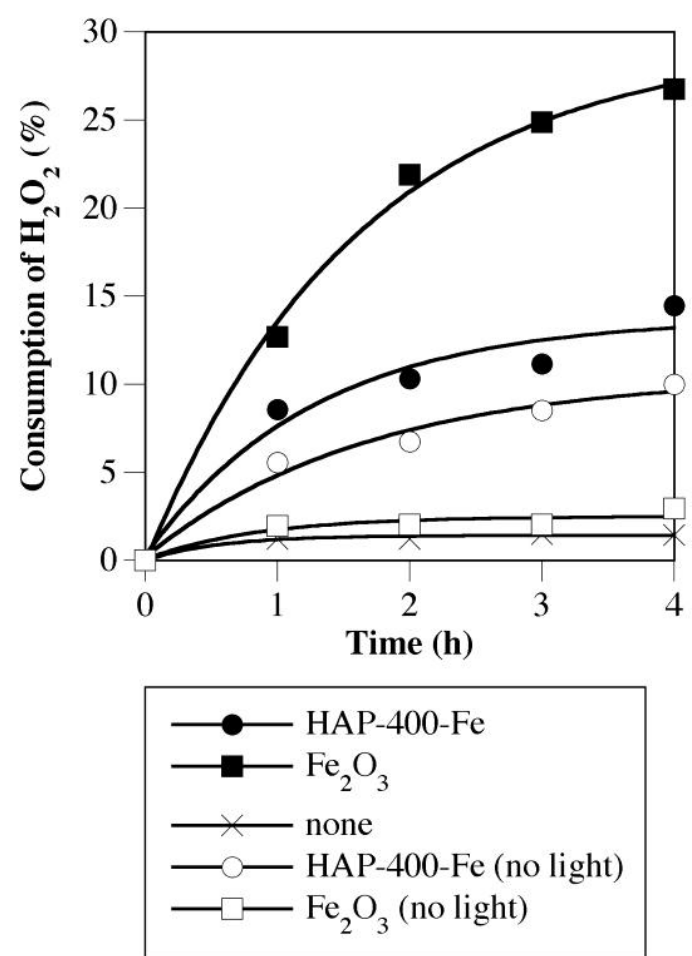

FIGURE 4 Degradation of $\mathrm{H}_{2} \mathrm{O}_{2}$ in the presence of $\mathrm{Fe}$ catalysts under black light irradiation.
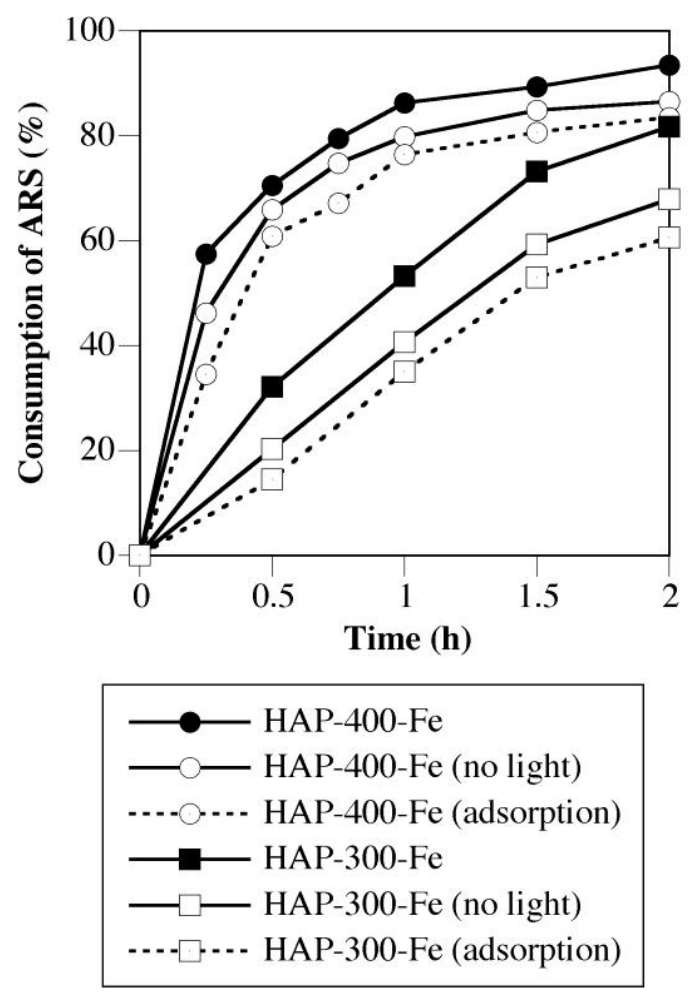

FIGURE 5 Photo-Fenton reaction of ARS with HAP-300-Fe and HAP-400-Fe. 
TABLE 1 Photo-Fenton reaction of dyes for $6 \mathrm{~h}$ at $25^{\circ} \mathrm{C}$ with $\mathrm{HAP}-400-\mathrm{Fe}^{(\mathrm{a})}$

\begin{tabular}{|c|c|c|c|c|}
\hline \multirow[b]{2}{*}{ Substrate $^{(\mathrm{b})}$} & \multicolumn{2}{|c|}{ Photo-Fenton } & \multirow{2}{*}{$\begin{array}{l}\text { Self-degradation } \\
(\%)^{(\mathrm{c}),(\mathrm{e})}\end{array}$} & \multirow{2}{*}{$\begin{array}{l}\text { Adsorption } \\
(\%)^{(\mathrm{c}),(\mathrm{f})}\end{array}$} \\
\hline & $\begin{array}{l}\text { Consumption } \\
(\%)^{(\mathrm{c})}\end{array}$ & $\begin{array}{c}\text { Mineralization } \\
(\%)^{(\mathrm{d})}\end{array}$ & & \\
\hline Alizarin red S (ARS) & 99 & 60 & $<1$ & 83 \\
\hline Alizarin $^{(\mathrm{g})}$ & 98 & 59 & 6 & 96 \\
\hline Neutral red & 55 & 27 & 37 & $<1$ \\
\hline Methyl red & 42 & 2 & $<1$ & 43 \\
\hline Methyl orange (MO) & 14 & $<1$ & $<1$ & $<1$ \\
\hline Congo red & 89 & 60 & $<1$ & 99 \\
\hline Indigo carmine & $>99$ & $<1$ & $<1$ & $<1$ \\
\hline
\end{tabular}

(a) ARS, $23 \mu \mathrm{M} ; \mathrm{H}_{2} \mathrm{O}_{2}, 10 \mathrm{mM}$; HAP-400-Fe, $0.5 \mathrm{~g} / \mathrm{L}$. (b) referred to SCHEME 1 . (c) determined by UV-VIS. (d) determined by TOC. (e) tested in the absence of $\mathrm{H}_{2} \mathrm{O}_{2}$. (f) tested in the absence of $\mathrm{H}_{2} \mathrm{O}_{2}$ without black light irradiation. (g) tested at $\mathrm{pH} 10$.

without black light irradiation was conducted, and similar time-dependent curves were plotted as follows: blank circles on a solid line are for HAP-400-Fe; blank squares on a solid line are for HAP-300-Fe. Time-adsorption curves under the similar reaction condition without $\mathrm{H}_{2} \mathrm{O}_{2}$ and black light irradiation were also plotted in FIGURE 5, where blank circles on a dashed line are for HAP-400-Fe and blank squares on a dashed line are for HAP-300-Fe. Obviously, HAP-400-Fe indicated much faster ARS consumption rate than HAP-300-Fe, especially within $1 \mathrm{hr}$. According to the previous paper, ${ }^{1}$ adsorption capacity of HAP-400-Fe for ARS at an adsorption equilibrium stage $\left(25^{\circ} \mathrm{C}, 30 \mathrm{hr}\right), 66$ $\mu \mathrm{mol} / \mathrm{g}$, was inferior to that of HAP-300-Fe, 91 $\mu \mathrm{mol} / \mathrm{g}$. We recognized that the present ARS consumption rates are subjected to adsorption velocity rather than adsorption capacity, or to kinetic control rather than thermodynamic control. The reactions under no black light irradiation (blank circles and squares) must have involved both adsorption and Fenton reaction; the latter is derived by $\mathrm{Fe}$ catalysis of $\mathrm{H}_{2} \mathrm{O}_{2}$ without light irradiation. ${ }^{34,35}$ Although both HAP-300-Fe and HAP-400-Fe exhibited a slight possibility of catalysis for Fenton reaction, the ARS consumptions were inferior to the cases of photo-Fenton reactions. Rate difference between photo-Fenton (filled circles and squares) and Fenton (blank circles and squares) reactions in HAP-400-Fe was smaller than that in HAP-300-Fe. However, we evaluated that HAP-400-Fe exhibiting higher ARS consumption rate is more useful than HAP-300-Fe from viewpoint of efficient and fast decoloration.

\subsection{Photo-Fenton reaction of miscellaneous dyes}

Photo-Fenton reaction of other dyes, namely alizarin, neutral red, methyl red, methyl orange (MO), Congo red, and indigo carmine, as shown in SCHEME 1, was investigated at $25^{\circ} \mathrm{C}$ for $6 \mathrm{~h}$ by using HAP-400-Fe. Although $\mathrm{pH}$ values of the reaction solutions were consistently adjusted to 7.0, the only case of alizarin was carried out at $\mathrm{pH} 10$ because of improving its solubility in water. The reaction result was summarized in TABLE 1, where "self-degradation" means evaluation of direct effect of black light irradiation to a substrate without $\mathrm{H}_{2} \mathrm{O}_{2}$, and "adsorption" means adsorption rate of a substrate under the similar reaction condition without black light irradiation and $\mathrm{H}_{2} \mathrm{O}_{2}$. ARS and alizarin, of which structures resemble each other (SCHEME 1), were consumed almost completely and mineralized more than 58\%. Similarly, Congo red was consumed at $89 \%$ and mineralized at $60 \%$. These three dyes indicating high consumptions exhibited high adsorptions over $80 \%$. Indigo carmine was completely consumed but never mineralized, indicating no adsorption $(<1 \%)$. Neutral red and methyl red were consumed at approximately half: The former indicated the most self-degradation rate and no adsorption, and the latter indicated a slight mineralization and moderate adsorption. MO indicated the lowest consumption at $14 \%$ and no 
TABLE 2 Effects of $\mathrm{Fe}$ catalyst and reaction time to consumption and mineralization in photo-Fenton reaction of ARS at $25^{\circ} \mathrm{C}$.

\begin{tabular}{ccccc}
\hline Catalyst & $\begin{array}{c}\text { Amount } \\
(\mathrm{mmol} \mathrm{Fe} / \mathrm{L})\end{array}$ & $\begin{array}{c}\text { Time } \\
(\mathrm{h})\end{array}$ & $\begin{array}{c}\text { Consumption } \\
(\%)^{(\mathrm{a})}\end{array}$ & $\begin{array}{c}\text { Mineralization } \\
(\%)^{(\mathrm{b})}\end{array}$ \\
\hline $\mathrm{HAP}-400-\mathrm{Fe}$ & 2.5 & 6 & 99 & 60 \\
& 2.5 & 20 & 99 & 72 \\
\hline $\mathrm{Fe}_{2} \mathrm{O}_{3}$ & 5.0 & 20 & 99 & 75 \\
\hline $\mathrm{FePO}_{4} \cdot 2 \mathrm{H} \mathrm{H}_{2} \mathrm{O}$ & 2.5 & 6 & 97 & 25 \\
\hline $\mathrm{FeOOH}$ & 2.5 & 6 & 82 & 23 \\
\hline
\end{tabular}

(c) determined by UV-VIS. (d) determined by TOC.

mineralization. Overviewing relationship between consumption and adsorption rates, it was considered that a substrate having high adsorbability on HAP-400-Fe is apt to indicate high consumption and/or mineralization.

\subsection{Comparison with other Fe catalysts}

For evaluation of HAP-400-Fe as a catalyst, photo-Fenton reaction of ARS was investigated by using other $\mathrm{Fe}$ catalysts, $\mathrm{Fe}_{2} \mathrm{O}_{3}, \mathrm{FePO}_{4} \cdot 2 \mathrm{H}_{2} \mathrm{O}$, and $\mathrm{FeOOH}$, under a definitive catalyst amount condition as follows: Fe mole number of each catalyst in a reaction solution was unified into $2.5 \mathrm{mmol} \mathrm{Fe} / \mathrm{L}$. The resulting time-dependent consumption curves within $2 \mathrm{~h}$ were shown in FIGURE 6. The order of apparent consumption rates was regarded as HAP-400-Fe $>\mathrm{Fe}_{2} \mathrm{O}_{3}>\mathrm{FePO}_{4} \cdot 2 \mathrm{H}_{2} \mathrm{O}>\mathrm{FeOOH}$. This implies that HAP-400-Fe having amorphic $\mathrm{FePO}_{4}$ on the surface ${ }^{30}$ has much higher catalytic activity than $\mathrm{FePO}_{4} \cdot 2 \mathrm{H}_{2} \mathrm{O}$, or $\mathrm{FePO}_{4}$ itself. The case of no catalyst affected a slight consumption, implying that $\mathrm{Fe}$ catalysis should be needed in the present condition. Prolonging reaction time up to 6 $\mathrm{h}$, ARS consumptions were obviously improved in the all $\mathrm{Fe}$ catalysts, as shown in TABLE 2. However, mineralization rates in $\mathrm{Fe}_{2} \mathrm{O}_{3}, \mathrm{FePO}_{4} \cdot 2 \mathrm{H}_{2} \mathrm{O}$, and $\mathrm{FeOOH}$ never exceeded the rate in HAP-400-Fe. After the reactions, all solution filtrates were analyzed by ICP to confirm whether Fe ion was eluted or not. All Fe concentrations in the filtrates were found to be under detection limit $(<0.1 \mathrm{ppm})$, being regarded as no elution. Consequently, we estimated that HAP-400-Fe featured the most efficient catalysis as a heterogeneous catalyst at least in the reaction of ARS.

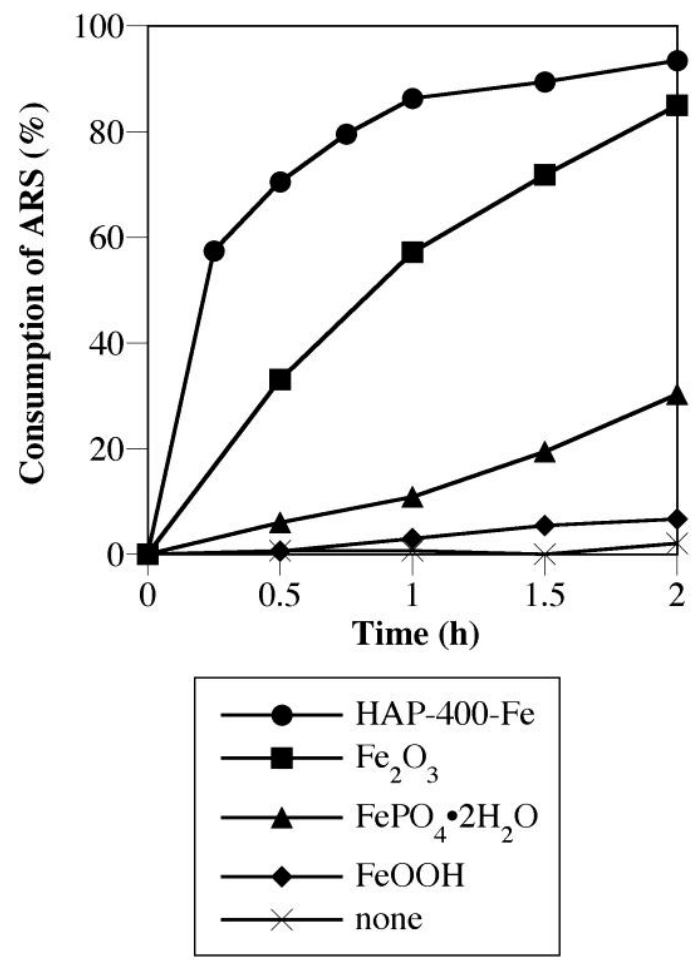

FIGURE 6 Time-consumption curves in photo-Fenton reaction of ARS with HAP-400-Fe, $\mathrm{Fe}_{2} \mathrm{O}_{3}, \mathrm{FePO}_{4} \cdot 2 \mathrm{H}_{2} \mathrm{O}, \mathrm{FeOOH}(2.5 \mathrm{mmol} \mathrm{Fe} / \mathrm{L})$.

The difference in effects of the Fe catalysts to ARS consumptions and mineralizations (TABLE 2) seems to be concerned with those surface properties 
and/or catalysis mechanisms. FIGURE 7 shows pore distributions of the Fe catalysts, and TABLE 3 summarizes the corresponding specific surface areas and total pore volumes. Obviously, HAP-300-Fe, HAP-400-Fe, and $\mathrm{FeOOH}$ bear numerous pores between 10 and $350 \AA$, or between 1 and $35 \mathrm{~nm}$ (FIGURE 7). Simultaneously, they have relatively large total pore volumes and specific surface areas, compared with $\mathrm{Fe}_{2} \mathrm{O}_{3}$ and $\mathrm{FePO}_{4} \cdot 2 \mathrm{H}_{2} \mathrm{O}$ (TABLE 3). However, those surface areas do not necessarily reflect the corresponding catalytic activities, or degrees of consumption and mineralization. For example, $\mathrm{FeOOH}$, which has the second largest surface area, indicated the lowest ARS consumption rate, and $\mathrm{Fe}_{2} \mathrm{O}_{3}$, which has the smallest specific surface area and total pore volume, indicated the second fastest consumption rate among the $\mathrm{Fe}$ catalysts (FIGURE 6). Adsorption of ARS on $\mathrm{Fe}_{2} \mathrm{O}_{3}, \mathrm{FePO}_{4} \cdot 2 \mathrm{H}_{2} \mathrm{O}$, and $\mathrm{FeOOH}$ was investigated at $25^{\circ} \mathrm{C}$ for $2 \mathrm{~h}$, but no adsorption on these catalysts was observed. Furthermore, FIGURE 8 indicates kinetic superiority of $\mathrm{Fe}_{2} \mathrm{O}_{3}$ rather than HAP-400-Fe in photo-Fenton reaction of $\mathrm{MO}$ in spite of lower adsorption rate for $\mathrm{Fe}_{2} \mathrm{O}_{3}$. Consequently, degradation rates of dyes are not always dependent on adsorbabilities of dyes on the present Fe catalysts. We considered that a more detailed kinetics study should be needed in the present photo-Fenton reaction.

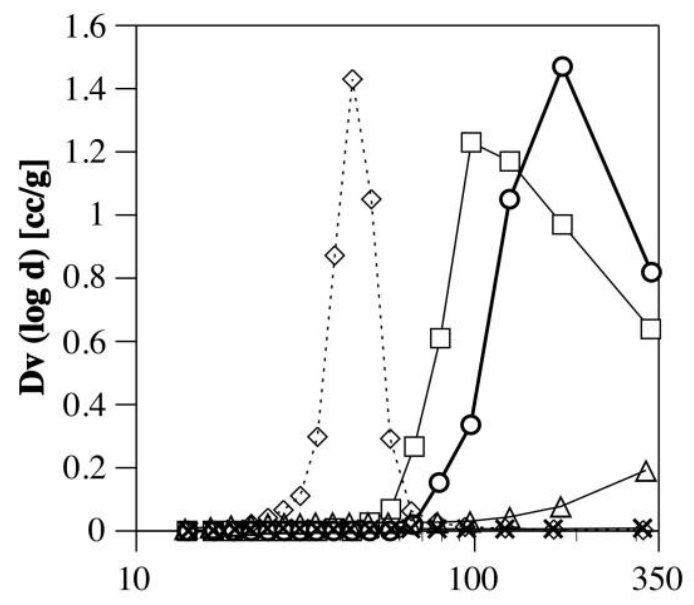

Pore Diameter (logarithm scale) [Å]

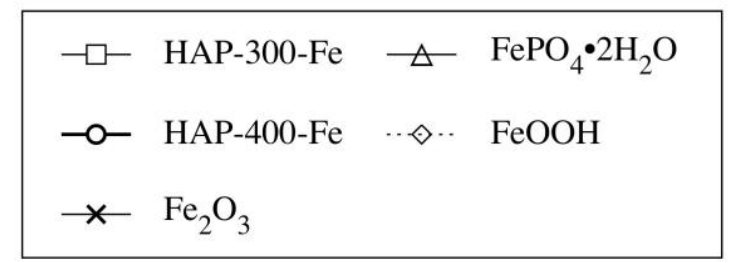

FIGURE 7 Pore diameter distribution of HAP-300-Fe, HAP-400-Fe, $\mathrm{Fe}_{2} \mathrm{O}_{3}, \mathrm{FePO}_{4} \cdot 2 \mathrm{H}_{2} \mathrm{O}$, and $\mathrm{FeOOH}$ by a $\mathrm{N}_{2}$-adsorption method.
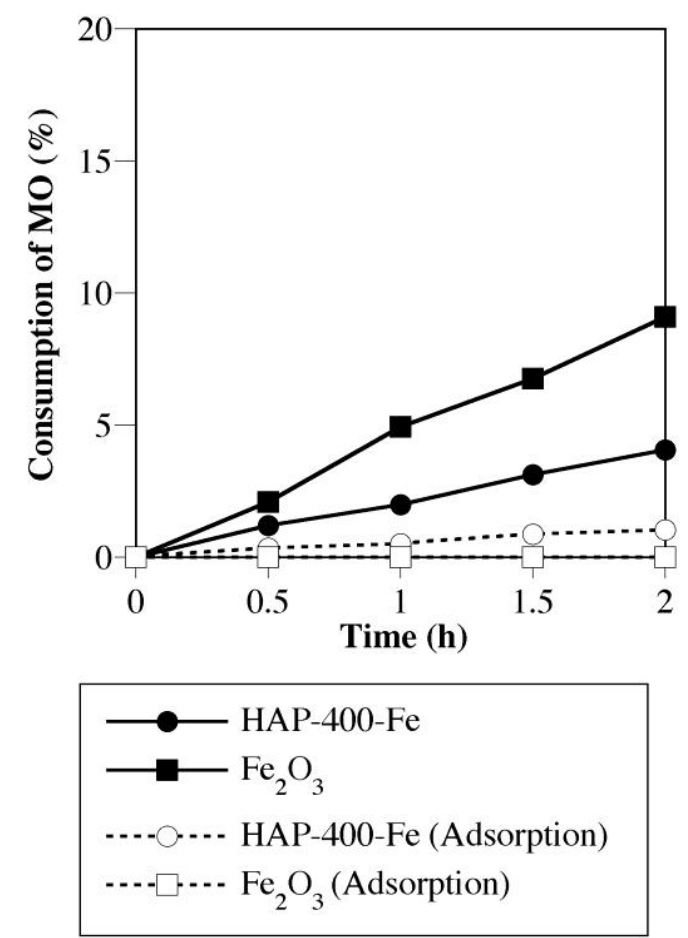

FIGURE 8 Time-consumption curves in photo-Fenton reaction of MO with HAP-400-Fe and $\mathrm{Fe}_{2} \mathrm{O}_{3}$.

TABLE 3 Specific surface areas and total pore volumes of Fe catalysts.

\begin{tabular}{ccc}
\hline Catalyst & $\begin{array}{c}\text { Specific } \\
\text { surface area } \\
\left(\mathrm{m}^{2} / \mathrm{g}\right)^{(\mathrm{a})}\end{array}$ & $\begin{array}{c}\text { Total pore } \\
\text { volume } \\
\left(\mathrm{cm}^{3} / \mathrm{g}\right)^{(\mathrm{b})}\end{array}$ \\
\hline $\mathrm{HAP}-300-\mathrm{Fe}$ & $170^{(\mathrm{c})}$ & 0.791 \\
$\mathrm{HAP}-400-\mathrm{Fe}$ & $145^{(\mathrm{c})}$ & 0.796 \\
$\mathrm{Fe}_{2} \mathrm{O}_{3}$ & $6.38^{(\mathrm{d})}$ & 0.021 \\
$\mathrm{FePO}_{4} \cdot 2 \mathrm{H}_{2} \mathrm{O}$ & $29.7^{(\mathrm{d})}$ & 0.200 \\
$\mathrm{FeOOH}$ & $169^{(\mathrm{d})}$ & 0.221 \\
\hline
\end{tabular}

(a) BET method. (b) evaluated from FIGURE 7.

(c) reference $36 . \quad$ (d) the present data.

\subsection{Kinetics based on Michaelis-Menten theory}

For a kinetics study, Michaelis-Menten theory ${ }^{31}$ (Eq. 1) is often employed to elucidate enzyme catalysis such as catalytic activity and affinity to a 
substrate. In Eq. 1, [S], [E], [ES], and [P] denote concentrations of substrate, enzyme, enzyme-substrate complex, and product, respectively. In the present study, the abbreviations "E" and "ES" can be translated into a Fe catalyst and a catalyst-substrate complex, respectively. The coefficient $k_{\text {cat }}$ denotes a kinetic constant of product generation, or turn over number (TON), which means an index of catalytic activity.

$$
[\mathrm{S}]+[\mathrm{E}] \rightleftharpoons[\mathrm{ES}] \stackrel{k_{\mathrm{cat}}}{\longrightarrow}[\mathrm{P}]+[\mathrm{E}] \quad(\text { Eq. } 1)
$$

Based on the above theory, Eq. 2 is derived and well-known as Michaelis-Menten equation: $v$, initial velocity; $V_{\max }$, maximum velocity; $K_{\mathrm{M}}$, Michaelis constant. The initial velocity $v$ increases proportionally with increase in the substrate concentration $[\mathrm{S}]$ at an early stage, or relatively low $[\mathrm{S}]$ value. However, if $[\mathrm{S}]$ becomes considerably large, $v$ turns out to approach to a constant and maximum value, namely $V_{\max }$. The Michaelis constant $K_{\mathrm{M}}$ implies degree of affinity of an enzyme to a substrate; the lower $K_{\mathrm{M}}$ value is regarded as the stronger affinity of the enzyme. Similarly in the present case, $K_{\mathrm{M}}$ can be translated into an affinity constant for a Fe catalyst.

$$
v=\frac{V_{\max }[\mathrm{S}]}{K_{\mathrm{M}}+[\mathrm{S}]}
$$

If reaction velocity is accomplished to $V_{\max }$, the following equation, Eq. 3, comes into effect: $[\mathrm{E}]_{0}$, initial concentration of enzyme, or that of Fe catalyst, followed by evaluation of $k_{\text {cat }}$.

$$
V_{\max }=k_{\text {cat }}[\mathrm{E}]_{0}
$$

The Michaelis-Menten equation (Eq. 2) is very useful for kinetic elucidation of almost catalytic reactions, but plotting between $[\mathrm{S}]$ (X-axis) and $v$ (y-axis) always features an upward convex curve, which is hardly used for actual evaluation of the constants $V_{\max }$ and $K_{\mathrm{M}}$. Alternatively, as shown in Eq. 4, Lineweaver-Burk equation, ${ }^{32}$ which is derived by reciprocal transformation from Eq. 2, is useful for instant evaluation of those constants. Plotting a straight line with $1 /[\mathrm{S}](\mathrm{x}$-axis) and $1 / v$ (y-axis) can give $K_{\mathrm{M}}$ and $V_{\max }$ values from a slope and an intercept on the plotting line, respectively.

$$
\frac{1}{v}=\frac{K_{\mathrm{M}}}{V_{\max }} \times \frac{1}{[\mathrm{~S}]}+\frac{1}{V_{\max }}
$$

FIGURE 9 reveals Lineweaver-Burk plots for the present photo-Fenton reaction of ARS in water by using HAP-300-Fe, HAP-400-Fe, and $\mathrm{Fe}_{2} \mathrm{O}_{3}$ (solid lines) and in phosphate buffer solution (PBS) by using HAP-400-Fe (a hashed line). In addition, FIGURE 10 indicates similar plots for $\mathrm{MO}$ in water by using HAP-400-Fe and $\mathrm{Fe}_{2} \mathrm{O}_{3}$. The constants, $V_{\max }, K_{\mathrm{M}}$, and $k_{\text {cat }}$, were evaluated from those FIGUREs and summarized in TABLE 4. Subsequently, $V_{\max } / K_{\mathrm{M}}$ values were evaluated and sited in TABLE 4. The $V_{\max } / K_{\mathrm{M}}$ is from Eq. 5, which is derived from Eq. 2 in the case of $K_{M} \gg[S]$, and probably regarded as an apparent first-order degradation rate constant, or interpreted as another index of catalytic activity, ${ }^{37,38}$ similarly to $k_{\text {cat }}$.

$$
v \cong \frac{V_{\max }}{K_{\mathrm{M}}} \times[\mathrm{S}] \quad\left(K_{\mathrm{M}}>>[\mathrm{S}]\right)
$$
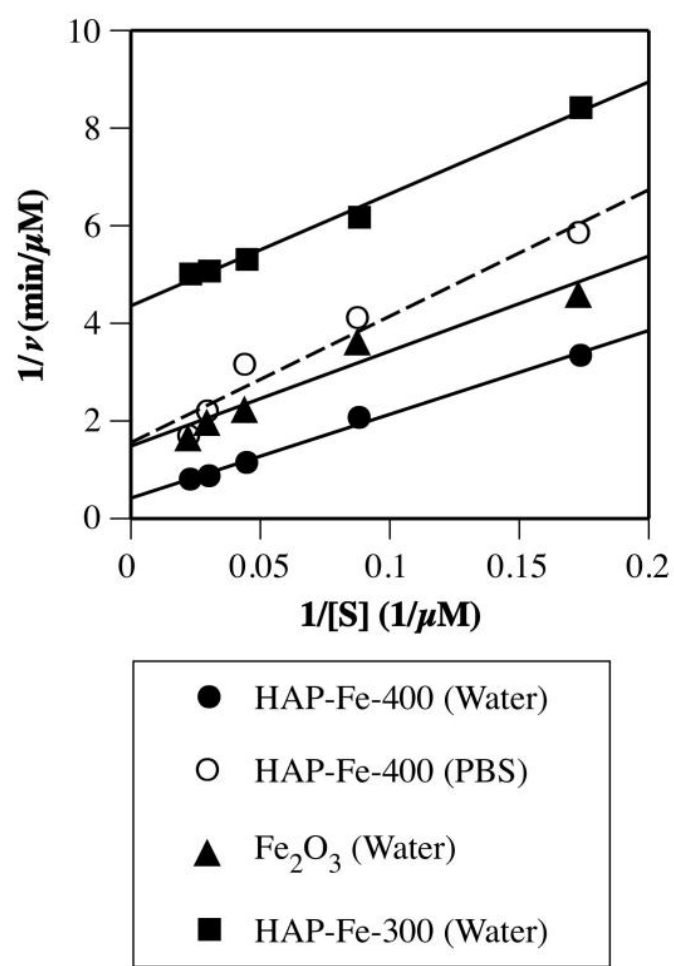

FIGURE 9 Lineweaver-Burk plots in photo-Fenton reaction of ARS with HAP-300-Fe, HAP-400-Fe, and $\mathrm{Fe}_{2} \mathrm{O}_{3}$ in water (solid line) or PBS (hashed line). 


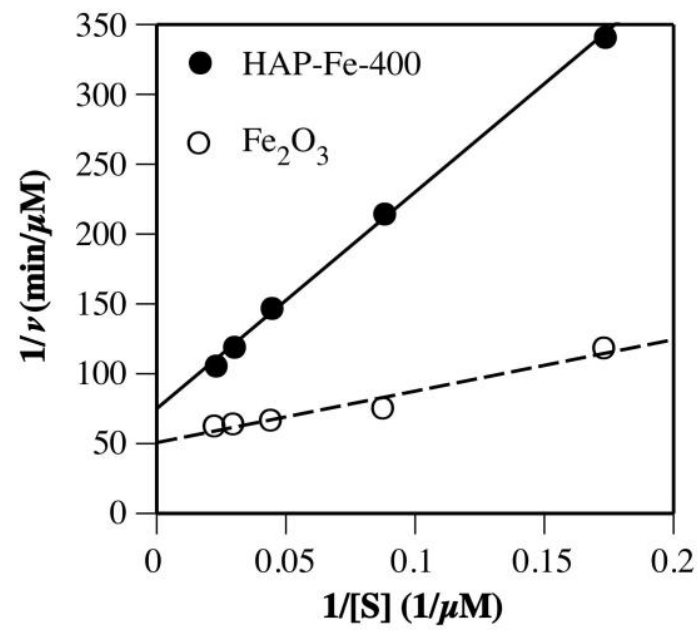

FIGURE 10 Lineweaver-Burk plots in photo-Fenton reaction of MO with HAP-400-Fe and $\mathrm{Fe}_{2} \mathrm{O}_{3}$ in water.

In photo-Fenton reaction of ARS in water, HAP-400-Fe indicated the largest $V_{\max }, k_{\text {cat }}$, and $V_{\text {max }} / K_{\mathrm{M}}$ values (TABLE 4 ). Among the Fe catalysts employed, HAP-400-Fe apparently exhibited the most efficient catalysis for ARS. However, $K_{\mathrm{M}}$ for HAP-400-Fe indicated the largest value, meaning the poorest affinity to ARS. As reported previously, ${ }^{1}$ the order of ARS adsorption capacity of $\mathrm{Fe}$ (III)-treated hydroxyapatites was HAP-300-Fe > HAP-400-Fe, but both of them have much larger adsorption capacities than $\mathrm{Fe}_{2} \mathrm{O}_{3}$, as described above (see in Section 3.4). Consequently, we considered that HAP-400-Fe has relatively large adsorption capacity to bear a substrate, but features weaker affinity to ARS than HAP-300-Fe and $\mathrm{Fe}_{2} \mathrm{O}_{3}$. Changing the reaction solvent from water to PBS in photo-Fenton reaction of ARS with HAP-400-Fe, $V_{\max }$ and $K_{\mathrm{M}}$ values were lowered to less than half. The decrease in $V_{\max }$ is possibly due to kinetically competitive interaction of ARS and solvent molecules with HAP-400-Fe surface, or inhibition of interaction of ARS molecules with $\mathrm{Fe}$ sites by phosphate ions $\left(\mathrm{PO}_{4}{ }^{3-}, \mathrm{HPO}_{4}{ }^{2-}, \mathrm{H}_{2} \mathrm{PO}_{4}{ }^{-}\right)$from PBS solvent. $^{39,} 40$ The other decrease in $K_{\mathrm{M}}$ or improvement of affinity is possibly due to interaction or adsorption mechanism between ARS and HAP-400-Fe. As described above (see in INTRODUCTION), ${ }^{1}$ adsorption mechanism of ARS on HAP-400-Fe is defined as a chelete form, in which neighboring carbonyl (C-9) and phenolate (C-1) groups of ARS make a chelation to a Fe site of HAP-400-Fe. The chelation form intensified ARS adsorption capacity of HAP-400-Fe from $66 \mu \mathrm{mol} / \mathrm{g}$ in water to $101 \mu \mathrm{mol} / \mathrm{g}$ in PBS. Consequently, the decrease in $K_{\mathrm{M}}$ value or increase in affinity is attributed to the increase in adsorption capacity. On the other hand, photo-Fenton reaction of MO in water resulted in a different feature. Although adsorption rate of $\mathrm{Fe}_{2} \mathrm{O}_{3}$ was lower than that of HAP-400-Fe (FIGURE 8), $\mathrm{Fe}_{2} \mathrm{O}_{3}$ indicated a superior catalytic property, or larger $V_{\text {max }}, k_{\text {cat }}$, and $V_{\text {max }} / K_{\mathrm{M}}$ values than those of HAP-400-Fe (TABLE 4). In addition, the $K_{\mathrm{M}}$ value of $\mathrm{Fe}_{2} \mathrm{O}_{3}$ was lower than that of HAP-400-Fe, meaning that $\mathrm{Fe}_{2} \mathrm{O}_{3}$ has higher affinity to MO than HAP-400-Fe. This result implies that adsorption affinity rather than adsorption amount possibly causes exhibition of efficient catalysis for photo-Fenton reaction of MO.<smiles>CN(C)c1ccc(N(C)C)c(N=O)c1</smiles><smiles>CN(C)c1ccc([N+](=O)[O-])cc1</smiles>

SCHEME 2 Reaction of DMNA with hydroxyl radical $\bullet \mathrm{OH}$.

As an alternative viewpoint of catalysis, we considered that generation rate of hydroxyl radical - $\mathrm{OH}$ as an active oxygen species from $\mathrm{H}_{2} \mathrm{O}_{2}$ is an important factor for progress of the present reaction. A convenient and indirect method ${ }^{33}$ using a nitroso compound, N, N-dimethyl-4-nitrosoaniline (DMNA), was employed for detection of $\bullet \mathrm{OH}$. DMNA is exclusively sensitive to react with $\cdot \mathrm{OH}$, involving oxidation of the original nitroso group into nitro group, as shown in SCHEME 2. Therefore, DMNA was investigated under the similar photo-Fenton reaction condition to evaluate $\cdot \mathrm{OH}$ generation ability of the present $\mathrm{Fe}$ catalysts. The result of this investigation was shown as time-dependent DMNA consumption plotting in FIGURE 11. Among the $\mathrm{Fe}$ catalysts, HAP-400-Fe apparently indicated the fastest rate, but its consumption includes adsorption rate at approximately $10 \%$ (white circles on a dashed line). $\quad \mathrm{Fe}_{2} \mathrm{O}_{3}$ indicated the second fastest consumption rate. $\mathrm{Fe}_{2} \mathrm{O}_{3}$ possibly makes catalysis in almost exclusive photo-Fenton reaction, since it indicated no adsorbability to DMNA (no plot in FIGURE 11). $\quad \mathrm{FePO}_{4} \cdot 2 \mathrm{H}_{2} \mathrm{O}$ indicated a little more superior rate than the case of no catalyst ("none"). The rate for $\mathrm{FeOOH}$ was less than the case of no 
TABLE 4 Michaelis-Menten constants ${ }^{(a)}$ for Fe catalysts in photo-Fenton reaction of dyes and DMNA at $25^{\circ} \mathrm{C}$.

\begin{tabular}{|c|c|c|c|c|c|c|}
\hline Substrate ${ }^{(\mathrm{b})}$ & Catalyst $^{(\mathrm{c})}$ & Solvent $^{(\mathrm{d})}$ & $\begin{array}{c}\mathrm{V}_{\max } \\
(\mu \mathrm{M} / \min )\end{array}$ & $\begin{array}{c}\mathrm{K}_{\mathrm{M}} \\
(\mu \mathrm{M})\end{array}$ & $\begin{array}{c}k_{\mathrm{cat}}\left[\mathrm{x} 10^{-6}\right] \\
\left(\mathrm{s}^{-1}\right)\end{array}$ & $\begin{array}{c}\mathrm{V}_{\max } / \mathrm{K}_{\mathrm{M}}\left[\mathrm{x} 10^{-4}\right] \\
\left(\mathrm{s}^{-1}\right)\end{array}$ \\
\hline \multirow[t]{4}{*}{ ARS } & HAP-300-Fe & water & 0.23 & 5.26 & 1.53 & 7.29 \\
\hline & HAP-400-Fe & water & 2.39 & 40.98 & 15.9 & 9.72 \\
\hline & HAP-400-Fe & PBS & 0.64 & 16.64 & 4.28 & 6.41 \\
\hline & $\mathrm{Fe}_{2} \mathrm{O}_{3}$ & water & 0.67 & 13.11 & 4.49 & 8.52 \\
\hline \multirow[t]{2}{*}{ MO } & HAP-400-Fe & water & 0.013 & 20.68 & 0.0889 & 0.105 \\
\hline & $\mathrm{Fe}_{2} \mathrm{O}_{3}$ & water & 0.019 & 7.28 & 0.132 & 0.435 \\
\hline \multirow[t]{2}{*}{ DMNA } & HAP-400-Fe & water & 0.15 & 17.41 & 1.01 & 1.44 \\
\hline & $\mathrm{Fe}_{2} \mathrm{O}_{3}$ & water & 0.052 & 4.32 & 0.345 & 2.00 \\
\hline
\end{tabular}

(a) equation 2 5. (b) ARS and MO, 5.8 46 $\mu \mathrm{M}$; DMNA, 2.5 40 $\mu \mathrm{M}$. (c) $2.5 \mathrm{mmol} \mathrm{Fe} / \mathrm{L} . \quad$ (d) adjusted to $\mathrm{pH} 7.0$ in water or to $\mathrm{pH} 6.8$ in PBS.

catalyst, implying the weakest $\bullet \mathrm{OH}$ generation ability of $\mathrm{FeOOH}$. Interestingly, the order of time-dependent DMNA consumption, HAP-400-Fe > $\mathrm{Fe}_{2} \mathrm{O}_{3}>\mathrm{Fe}_{2} \mathrm{O}_{3} \cdot 2 \mathrm{H}_{2} \mathrm{O}>\mathrm{FeOOH}$, was found to be consistent with that of time-dependent ARS consumption (FIGURE 6). Further, kinetic investigation using DMNA based on Michaelis-Menten theory was conducted to elucidate more detailed catalysis concerned with $\cdot \mathrm{OH}$ generation. Similarly to the case of ARS (FIGURE 9) and MO (FIGURE 10), Lineweaver-Burk plotting was carried out in the reaction of DMNA as shown in FIGURE 12, followed by evaluation of the constants, $V_{\text {max }}, K_{\mathrm{M}}, k_{\text {cat }}$, and $V_{\max } / K_{\mathrm{M}}$ as summarized in TABLE 4. The values of $V_{\text {max }}, K_{\mathrm{M}}$, and $k_{\text {cat }}$ for HAP-400-Fe were larger than those for $\mathrm{Fe}_{2} \mathrm{O}_{3}$, and this tendency is same as the case of ARS. Nevertheless, $V_{\max } / K_{\mathrm{M}}$ value of HAP-400-Fe was lower than that of $\mathrm{Fe}_{2} \mathrm{O}_{3}$, implying that apparent first order rate of DMNA consumption rate, or $\bullet \mathrm{OH}$ generation rate for $\mathrm{Fe}_{2} \mathrm{O}_{3}$ was faster than that for HAP-400-Fe. FIGURE 4 also indicates time-consumption curves in investigation of degradation of $\mathrm{H}_{2} \mathrm{O}_{2}$ to $\mathrm{H}_{2} \mathrm{O}$ and $\mathrm{O}_{2}$ under black light irradiation by using HAP-400-Fe and $\mathrm{Fe}_{2} \mathrm{O}_{3}$, and afforded a definitive proof of superior $\mathrm{H}_{2} \mathrm{O}_{2}$ degradation rate in $\mathrm{Fe}_{2} \mathrm{O}_{3}$, compared with that in HAP-400-Fe. In addition, difference in rates between black light irradiation (filled square) and no irradiation (blank square) by using $\mathrm{Fe}_{2} \mathrm{O}_{3}$ was much larger than that by using HAP-400-Fe. Since the rate for no irradiation by using $\mathrm{Fe}_{2} \mathrm{O}_{3}$ was rarely different from that for a blank test ("none"), it is
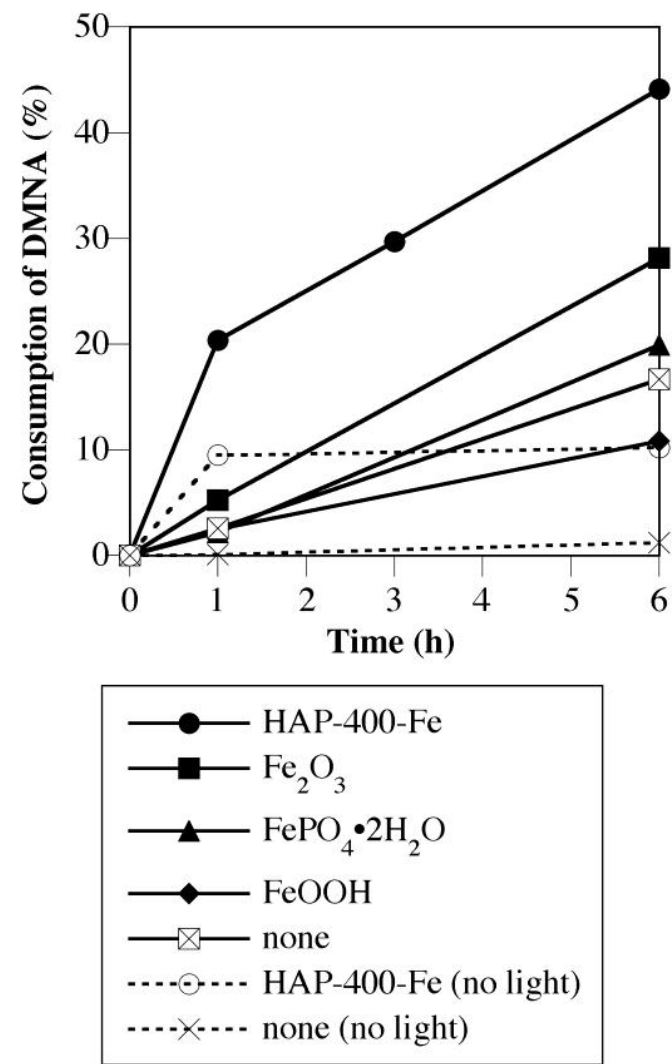

FIGURE 11 Time-consumption curves in reaction of DMNA under a similar photo-Fenton reaction condition $\left(25^{\circ} \mathrm{C}, 6 \mathrm{~h}\right)$. The expression "none" means the condition without $\mathrm{Fe}$ catalyst, and "no light" means without black light irradiation. 
translated that $\mathrm{Fe}_{2} \mathrm{O}_{3}$ can catalyze decomposition of $\mathrm{H}_{2} \mathrm{O}_{2}$ into $\bullet \mathrm{OH}$ efficiently. On the other hand, $\mathrm{H}_{2} \mathrm{O}_{2}$ is possibly easy to be adsorbed on HAP-400-Fe rather than $\mathrm{Fe}_{2} \mathrm{O}_{3}$. Therefore, catalytic ability of $\mathrm{H}_{2} \mathrm{O}_{2}$ decomposition into $\cdot \mathrm{OH}$ by $\mathrm{Fe}_{2} \mathrm{O}_{3}$ is considered to be higher than that by HAP-400-Fe. However, overviewing whole catalytic behaviors, HAP-400-Fe is regarded as an excellent catalyst since it indicated large pore volume (TABLE 3 ), relatively high $k_{\text {cat }}$ values (TABLE 4), and higher mineralization ability in photo-Fenton reaction of ARS than the other $\mathrm{Fe}$ catalysts (TABLE 2).

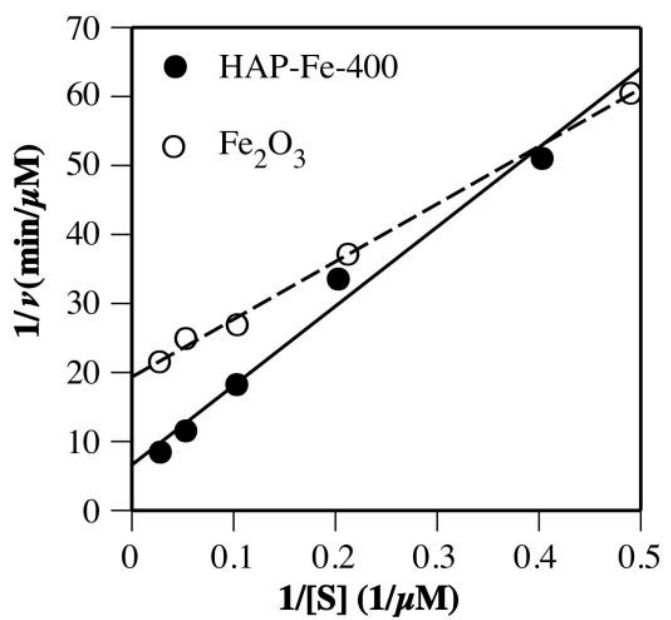

FIGURE 12 Lineweaver-Burk plots in photo-Fenton reaction of DMNA with HAP-400-Fe and $\mathrm{Fe}_{2} \mathrm{O}_{3}$ in water.

\subsection{Catalysis mechanism}

Judging from the kinetic results, the present $\mathrm{Fe}$ catalysts simultaneously play two significant roles in photo-Fenton reaction: One is catalysis of hydroxyl radical $\cdot \mathrm{OH}$ generation, and the other is degradation (oxidation) of a dye. Adsorbability of dyes or $\mathrm{H}_{2} \mathrm{O}_{2}$ on the $\mathrm{Fe}$ catalysts also must be deeply concerned with the two roles. Therefore, the following catalysis mechanism, referred to the report of Tao et al., ${ }^{3}$ was raised as shown in SCHEME 3. The courses (a) to (d) represent $\mathrm{H}_{2} \mathrm{O}_{2}$ degradation catalysis or $\cdot \mathrm{OH}$ generation routs, and the other courses (e) and (f) represent degradation catalysis of dyes or substrates. The course (a) indicates that a Fe site interacts with a $\mathrm{H}_{2} \mathrm{O}_{2}$ molecule to give a catalyst- $\mathrm{H}_{2} \mathrm{O}_{2}$ complex constructed by coordinate bond, involving equilibrium. The catalyst- $\mathrm{H}_{2} \mathrm{O}_{2}$ complex is converted to a peroxide surface structure $\mathrm{Fe}-\mathrm{OOH}$ in the next course (b). Under black light irradiation, the subsequent photolysis of $\mathrm{Fe}-\mathrm{OOH}$ instantly occurs as shown in the course (c) to afford a hydroxyl radical $\bullet \mathrm{OH}$ and an unstable super-oxidized structure $\mathrm{Fe}(\mathrm{IV})=\mathrm{O},{ }^{3,41}$ namely ferryl state iron, on catalyst surface. There are some reports ${ }^{6,11,12}$ on an alternative reductive mechanism, which involves reduction of $\mathrm{Fe}$ (III) to $\mathrm{Fe}$ (II) by treatment of $\mathrm{H}_{2} \mathrm{O}_{2}$. However, the present oxidative mechanism from $\mathrm{Fe}$ (III) to $\mathrm{Fe}(\mathrm{IV})$ state is considered to be reasonable for the present photo-Fenton reaction, judging from other preceding reports, ${ }^{42,43}$ in which $\mathrm{Fe}(\mathrm{III})$-porphyrin complex catalysts can be oxidized to $\mathrm{Fe}(\mathrm{IV})$ states by $\mathrm{H}_{2} \mathrm{O}_{2}$. We believe that this $\mathrm{Fe}(\mathrm{IV})$ producing theory should be applied to the cases using tightly $\mathrm{Fe}(\mathrm{III})$-immobilized catalysts, or similarly to the present heterogeneous $\mathrm{Fe}$ catalysts. Especially in HAP-300-Fe and HAP-400-Fe, the Fe sites were immobilized on the amorphic $\mathrm{FePO}_{4}$-like surfaces. ${ }^{1,} 30$ The unstable $\mathrm{Fe}(\mathrm{IV})=\mathrm{O}$ structure is easily subjected to water attack to give the original $\mathrm{Fe}$ (III) state and another $\cdot \mathrm{OH}$ as shown in the course (d). Regardless of any catalyst employed, both reaction rates in the course (c) and (d) are probably very fast. Therefore, we considered that total $\bullet \mathrm{OH}$ generation rate is controlled in the course (b) rather than the course (a). HAP-400-Fe can make many $\mathrm{H}_{2} \mathrm{O}_{2}$-catalyst complexes in its large pores in the course (a). The catalyst- $\mathrm{H}_{2} \mathrm{O}_{2}$ complex in HAP-400-Fe are slowly converted to $\mathrm{Fe}-\mathrm{OOH}$ state in the course (b) for the sake of low affinity to $\mathrm{H}_{2} \mathrm{O}_{2}$ (the large $\mathrm{K}_{\mathrm{M}}$ value for DMNA, TABLE 4), followed by slow generation of $\bullet \mathrm{OH}$ in the course (c) and (d). $\mathrm{Fe}_{2} \mathrm{O}_{3}$ has small capacity for bearing the complexes in the course (a). Nevertheless, it efficiently and quickly generates $\mathrm{Fe}-\mathrm{OOH}$ states in the course (b) and $\cdot \mathrm{OH}$ species in the next courses because of its high affinity to $\mathrm{H}_{2} \mathrm{O}_{2}$.

TABLE 5 Recycling test of HAP-400-Fe in photo-Fenton reaction of ARS for $6 \mathrm{~h}$ at $25^{\circ} \mathrm{C}^{(\text {a) }}$

\begin{tabular}{ccc}
\hline Time(s) & $\begin{array}{c}\text { Consumption } \\
(\%)^{(\mathrm{b})}\end{array}$ & $\begin{array}{c}\text { Mineralization } \\
(\%)^{(\mathrm{c})}\end{array}$ \\
\hline 1st & 99 & 60 \\
2nd & 99 & 54 \\
3rd & 99 & 54 \\
4th & 99 & 50 \\
5th & 99 & 50 \\
\hline
\end{tabular}

(a) ARS, $23 \mu \mathrm{M} ; \mathrm{H}_{2} \mathrm{O}_{2}, 10 \mathrm{mM}$; HAP-400-Fe, $0.5 \mathrm{~g} / \mathrm{L}$. (b) determined by UV-VIS.

(c) determined by TOC. 


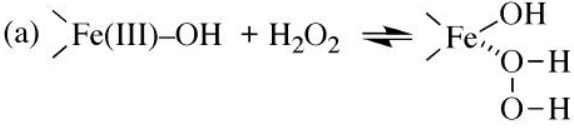

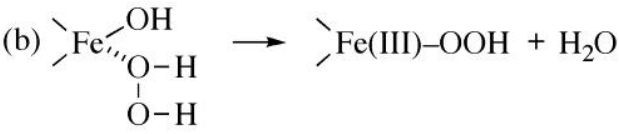

(c) $\mathrm{i}$ Fe(III)-OOH $+\mathrm{h} v \rightarrow$ $\mathrm{Fe}(\mathrm{IV})=\mathrm{O}+\bullet \mathrm{OH}$

(d) ${ }^{\prime} \mathrm{Fe}(\mathrm{IV})=\mathrm{O}+\mathrm{H}_{2} \mathrm{O} \longrightarrow \mathrm{Fe}(\mathrm{III})-\mathrm{OH}+\bullet \mathrm{OH}$

(e) ${ }^{\prime} \mathrm{Fe}-\mathrm{X}+$ Substrate $=\mathrm{Fe}_{\text {"' }}^{-\mathrm{X}}$ Substrate $\mathrm{X}=-\mathrm{OH},-\mathrm{OOH},=\mathrm{O}$

(f) Substrate* $+\bullet \mathrm{OH} \longrightarrow$ Degraded or mineralized products

*Complexed (e) or non-complexed substrate

SCHEME 3 A possible catalysis mechanism in the present photo-Fenton reaction.

From a viewpoint of catalyst-substrate complex as shown in the course (e), HAP-400-Fe has a possibility to produce large amount of the catalyst-substrate complexes in equilibrium, due to its large pore volume (TABLE 3) and adsorption capacity, ${ }^{1}$ similarly to the case of $\mathrm{H}_{2} \mathrm{O}_{2}$ mentioned above. On the other hand, $\mathrm{Fe}_{2} \mathrm{O}_{3}$ affords small amount of the complexes because of its small pore volume and adsorption capacity. Subsequently, a substrate is subjected to attacks of $\cdot \mathrm{OH}$ species, followed by degradation and mineralization, regardless of whether the substrate is complexed with a Fe site or not, as shown in the course (f). HAP-400-Fe can bear many complexed substrates to induce effective $\cdot \mathrm{OH}$ attacks within its pores. Consequently, its $V_{\max }$ and $k_{\text {cat }}$ values for ARS were larger than those of $\mathrm{Fe}_{2} \mathrm{O}_{3}$ (TABLE 4). In addition, further and repeated attacks of $\cdot \mathrm{OH}$ species are essential for effective mineralization of oxidized or degraded substrates into $\mathrm{CO}_{2}$ and $\mathrm{H}_{2} \mathrm{O}$ in $\mathrm{Fe}$ catalyst pores. The larger pore volume should enable the higher mineralization in spite of slow $\bullet \mathrm{OH}$ generation. Actually, HAP-400-Fe with relatively huge pore volume indicated the most effective mineralization of ARS among the $\mathrm{Fe}$ catalysts, and extension of reaction time resulted in increase in ARS mineralization (TABLE 2). On the other hand, $\mathrm{Fe}_{2} \mathrm{O}_{3}$ can fast generate $\cdot \mathrm{OH}$, and indicate the higher degradation rate (FIGURE 8 and TABLE 4). However, small pore volume of $\mathrm{Fe}_{2} \mathrm{O}_{3}$ afforded the lower ARS mineralization ability (TABLE 2). Using twice amount of HAP-400-Fe resulted in moderate improvement of ARS mineralization, as shown in TABLE 2. We had supposed that increase in catalyst amount would improve generation and attack frequency of $\bullet \mathrm{OH}$ species to accelerate initial oxidation of ARS. Contrary to the supposition, the increase in catalyst amount might cause lowering concentration of degraded products existing in each pore pocket to decelerate mineralization rate. Furthermore, HAP-400-Fe exhibited good recycling utility as shown in TABLE 5. The catalytic activity was hardly deteriorated: Five times repeating uses never invalidated complete consumption of ARS, and made marginal decrease in mineralization (down to $50 \%$ ). We found that HAP-400-Fe repeatedly works in the catalysis mechanism mentioned in SCHEME 3. From a comprehensive viewpoint, we considered that HAP-400-Fe is an excellent heterogeneous catalyst for photo-Fenton reaction.

\section{CONCLUSION}

The $\mathrm{Fe}(\mathrm{III})$-treated hydroxyapatite, HAP-400-Fe, indicated efficient catalytic activity for photo-Fenton reaction. Although rate or generation ability of $\bullet \mathrm{OH}$ species of HAP-400-Fe is lower than $\mathrm{Fe}_{2} \mathrm{O}_{3}$, residence time of substrate and $\mathrm{H}_{2} \mathrm{O}_{2}$ molecules in HAP-400-Fe pores is longer than that time in $\mathrm{Fe}_{2} \mathrm{O}_{3}$ pores because of high adsorption capacity of HAP-400-Fe. Organic materials in natural waters such as humic substances ${ }^{44}$ and agrichemicals may be also degraded by using the present photo-Fenton reaction system. In addition, from catalysis of HAP-400-Fe even in PBS, degradation of biomolecules such as proteins and nucleic acids may be accomplished under physiologically suitable conditions existing phosphate ions. In a future, application of $\mathrm{Fe}$ (III)-treated hydroxyapatite to water purification system is expected as a high value-added catalyst for photo-Fenton reaction because of its facile repeating availability.

\section{REFERENCES}

1. T. Moriguchi, S. Nakagawa, F. Kaji, Phosphorus Res. Bull., 24, 62 (2010).

2. T. W. Williams Jr., Stain Technol., 16, 23 (1941).

3. J. He, X. Tao, W. Ma, J. Zhao, Chem. Lett., 31, 86 (2002).

4. E. V. Kuznetsova, E. N. Saninov, L. A. Vostrikova, G. V. Echevskii, Water Sci. Technol., 49, 109 (2004). 
5. D. Li, T. Yuranova, P. Albers, J. Kiwi, Water Res., 38, 3541 (2004).

6. J. Feng, X. Hu, P. L. Yue, Environ. Sci. Technol., 38, 269 (2004).

7. J. Feng, X. Hu, P. L. Yue, Environ. Sci. Technol., 38, 5773 (2004).

8. J. Feng, X. Hu, P. L. Yue, Water Res., 39, 89 (2005).

9. J. Feng, X. Hu, P. L. Yue, Water Res., 40, 641 (2006).

10. Q. Zhang, W. F. Jiang, H. L. Wang, M. D. Chen, J. Hazard. Mater., 176, 1058 (2010).

11. M. B. Kasiri, A. Aleboyeh, H. Aleboyeh, Water Res. Technol., 61, 2143 (2010).

12. M. B. Kasiri, H. Aleboyeh, A. Aleboyeh, Environ. Technol., 31, 165 (2010).

13. G. B. de la Plata, O. M. Alfano, A. E. Cassano, Water Sci. Technol., 61, 3109 (2010).

14. G. Zhang, Y. Gao, Y. Zhang, Y. Guo, Environ. Sci. Technol., 44, 6384 (2010).

15. S. Q. Liu, S. Cheng, L. R. Feng, X. M. Wang, Z. G. Chen, J. Hazrd. Mater., 182, 665 (2010).

16. Y. H. Gong, H. Zhang, Y. L. Li, L. J. Xiang, S. Royer, S. Valange, J. Barrault, Water Sci. Technol., 62, 1320 (2010).

17. L. F. Gonzalez-Bahamon, D. F. Hoyos, N. Benitez, C. Pulgarin, Chemosphere, 82, 1185 (2011).

18. F. Ji, C. Li, J. Zhang, L. Deng, J. Hazrd. Mater., 186, 1979 (2011).

19. A. Matilainen, M. Sillanpaa, Chemosphere, 80, 351 (2010).

20. J. J. Pignatello, Environ. Sci. Technol., 26, 944 (1992).

21. Y. Sun, J. J. Pignatello, Environ. Sci. Technol., 27, 304 (1993).

22. B. Ruppert, R. Bauer, G. Heisler, S. Novalic, Chemosphere, 3, 339 (1993).

23. J. Kiwi, C. Pulgarin, P. Peringer, Appl. Catal., B-Environmental, 3, 335 (1994).

24. N. H. Ince, G. Tezcanli, Water Sci. Technol., 40, 183 (1999).
25. J. L. Acero, F. J. Benitez, F. J. A. L. Leal, Water Sci. Technol., 44, 31 (2001).

26. H. Aoki, M. Akao, M. Toho, S. Hasegawa, and H. Ukegawa, Ceramics, 24, 614 (1989).

27. T. Moriguchi, K. Yano, S. Nakagawa, F. Kaji, J. Colloid Interface Sci., 260, 19 (2003).

28(16). N. Matsuda, F. Kaji, T. Yamagami, M. Sakurai, T. Watanabe, Inorg. Matter. 5, 398 (1998).

29(17). S. Nakagawa, F. Kaji, T. Yamagami, M. Sakurai, T. Watanabe, Phosphorus Res. Bull. 14, 119 (2002).

30. T. Moriguchi, S. Nakagawa, F. Kaji, Phosphorus Res. Bull. 22, 54 (2008).

31. L. Michaelis, M. Menten, Biochem. Zeitung, 49, 333 (1913).

32. P. Atkins, J. de Paula, in Physical Chemistry for the Life Sciences, (W. H. Freeman and Company, New York, USA, 2006), pp. 309-313.

33. W. Bors, C. Michel, M. Saran, Eur. J. Biochem., 95, 621 (1979).

34. B. M. Voelker, B. Sulzberger, Environ. Sci. Tecnol., 30, 1106 (1996).

35. S. Park, T. Yoon, Desalination, 208, 181 (2007).

36. T. Moriguchi, Phosphorus Lett.(Japanese), 72, p.10 (2011).

37. J. W. Williams, D. B. Northrop, J. Biol. Chem., 253, 5908 (1978).

38. K. Radika, D. B. Northrop, Antimicrob. Agents Chemother., 25, 479 (1984).

39. L. C. Bell, A. M. Posner, J. P. Quirk, Nature, 239, 515 (1972).

40. L. C. Bell, A. M. Posner, J. P. Quirk, J. Colloid Interface Sci. 42, 250 (1973).

41. B. Meunier, Chem. Rev., 92, 1411 (1992).

42. K. Bian, Z. Gao, N. Weisbrodt, F. Murad, Proc. Natl. Acad. Sci., 100, 5712 (2003).

43. N. G. Giri, S. M. S. Chauhan, Catal. Commun., 10, 383 (2009).

44. E. A. Ghabbour, G. Davies, in Humic SubstancesVersatile Components of Plants, Soil, and Water, (The Royal Society of Chemistry, Cambridge, UK, 2000). 